Milica D. Obadović ${ }^{1}$

Rado Maksimović ${ }^{2}$

UDK 330.322:336.76>(497.11 Beograd)

Mirjana M. Obadović ${ }^{3}$

Preliminary paper

Prethodno priopćenje

\title{
THE ESTIMATE OF THE MARKET RISK BY THE APPLICATION OF HISTORICAL SIMULATION METHOD IN THE PERIOD OF GROWTH OF STOCK EXCHANGE INDICES ON BELGRADE STOCK EXCHANGE
}

\begin{abstract}
In Serbia there existed a period of investment growth, which reflected itself on the growth of stock market indices. The aim of this paper is to evaluate market risk at the Serbian market in period of investment growth, applying the method of historical simulation to a portfolio consisting of shares that are continuously traded at the Belgrade Stock Exchange, for which the data existed, since the Serbian stock exchange market is a young one, practically beginning. Method verification was carried out at different confidence levels, which demonstrated that the method underestimated the risk for the confidence level of $99 \%$.
\end{abstract}

KEY WORDS: market risk, Value-at-risk (VaR) model, historical simulation method, financial market

JEL CLASSIFICATION: C51, C52, G21

\section{INTRODUCTION}

Risk management represents the core activity for companies operating in the financial market. Whether the companies are passively accepting financial risks or trying to achieve a competitive advantage by exposing themselves to financial risks within reasonable limits, these risks should be carefully appraised due to their potential danger of causing losses.

To facilitate the analysis and to understand the risk that financial institutions are exposed to, it is common practice to classify risks into several basic risk types according to their main causes. According to their origins, the financial risks are thus classified into market, credit and operating risks. Broadly speaking, market risk refers to changes in the value of financial instruments or contracts held by a firm due to unpredictable fluctuations

\footnotetext{
${ }^{1}$ MSc in economics, currently at PhD studies at Department of Finance, Banking, Accounting and Revision, Faculty of Economics Subotica, University of Novi Sad, Subotica, e-mail: mobadovic@yahoo.co.uk.

$2 \mathrm{PhD}$, Department of Industrial Engineering and Management, Faculty of Technical Sciences, University of Novi Sad, Novi Sad, e-mail: rado@uns.ac.rs.

${ }^{3} \mathrm{MSc}$ in economics, currently at $\mathrm{PhD}$ studies at Department of Industrial Engineering and Management, sub major Engineering and Insurance Management, Faculty of Technical Sciences, University of Novi Sad, Novi Sad, e-mail: mirjanaobadovic@hotmail.com.
} 
in prices of traded assets and commodities as well as fluctuations in interest and exchange rates and other market indices. However, when the core activity of a business is to hold portfolios of assets, it would be dangerous to ignore their potential change in value. (Koenig, 2004).

Various models are used when analyzing such risks. One of the models used for market risk evaluation is the Value-at-Risk (VaR) model.

Value-at-risk (VaR) measures the worst expected loss over a given time interval under normal market conditions at a given confidence level (Dowd, 1998). Based on firm scientific foundations, VaR provides users with a summary measures of market risk. VaR is method of assessing risk that uses standard statistical techniques routinely used in other technical fields (Jorion, 1997). For instance, a bank might say that the daily VaR of it trading portfolio is $\$ 40$ million at the $99 \%$ confidence level. In other words, there is only $1 \%$ probability from $100 \%$, under normal market conditions, for a loss greater than $\$ 40$ million to occur. VaR measures risk using the same measurement units as banks - e.g. \$. Shareholders and managers may thus decide whether they consider a given risk level appropriate. In case they are not comfortable with the preffered risk level, the very process leading to VaR calculations may be utilized to make a decision on risk mitigation. Although it virtually always represents a loss, VaR is conventionally reported as a positive number. A negative VaR would imply the portfolio has a high probability of making a profit, for example a one-day $5 \% \mathrm{VaR}$ of negative $\$ 1$ million implies the portfolio has a 95\% chance of making $\$ 1$ million or more over the next day (Crouhy, Mark, Galai, 2001).

Financial institutions developed VaR as a general measure of economic loss, which may correspond both to the risk of individual items and the aggregate portfolio risk. The VaR approach originated as a methodology for market risk measurement, but the possibility of wider application was soon perceived. Besides the mentioned primary function, VaR methodology may also be used to make investment decisions by reevaluating the yield to risk relationship, ensuring a more consistent and integrated risk management. It was likewise understood that VaR methodology may be implemented to measure and manage other kinds of risk such as: liquidity risk, credit risk, cash flow risk, and even some of the operating and legal risks. In short, $\mathrm{VaR}$ creates possibilities for new approaches to comprehensive risk management.

During the eighties, large financial institutions (Bankers Trust, Chase Manhattan Bank, Citibank and others) began publishing the application of $\mathrm{VaR}$ in risk management systems. To implement this concept, a large amount of mutually interchangeable data was required, which was a huge problem until the appearance of RiskMetrics ${ }^{1}$. It consists of detailed technical documentation, as well as the covariance matrix for several hundred key points, which were updated daily. Since J.P. Morgan's RiskMetrics were published in 1994, there was a swift expansion of research into VaR methodology. Although the zone of evaluating and analyzing market risk exposure remained the main field of VaR implementation, applications were expanded to other types of risk as well.

In the last few years, many financial institutions have accepted VaR as an instrument for evaluating information on their portfolio positions. The regulatory authorities of most countries have recognized and acknowledge the VaR approach as one of several methods for

\footnotetext{
${ }^{1}$ RiskMetrics is a free service offered by JP Morgan in 1994, to promote VaR as a risk measurement tool.
} 
measuring the market risk of financial institutions. Apart from its conceptual appeal, its popularity was promoted by the Basel Committee ${ }^{1}$, which allowed banks to calculate their capital requirements for market risks using VaR methodology. In order to calculate VaR, banks may choose between the historical simulation method, analytical method and MonteCarlo simulation.

The idea of the historical simulation method is to estimate VaR values without creating serious assumptions on return distribution. Recent empirical return distribution is used for VaR values assessment. This type of approach is based on the assumption that the near future is very much like the recent past and that recent past data may be utilized for near future risk assessment. This assumption might be valid in any given context, however it is not necessarily so.

Historical simulation methods are intuitive and conceptually simple, providing results that are easy to communicate to senior managers or bank supervisors or rating agencies. Since they do not depend on parametric assumptions about the behavior of market variables, they can accommodate heavy tails, skew ness, and any other non-normal features that can cause problems for parametric approaches, including Monte-Carlo simulation. Historical simulation approaches can be modified to allow the influence of observations to be weighted (e.g. by season, age, or volatility). They use data that are readily available, either from public sources or from in-house data sets.

The weaknesses of historical simulation stem from the fact that results are completely dependent on the data set. If the data period was unusually quiet (or unusually volatile) and conditions have recently changed, historical simulation will tend to produce VaR estimates that are too low (high) for the risks we are actually facing. Similarly, historical simulation approaches are sometimes slow to reflect major events, such as the increases in risk associated with sudden market turbulence. In general, historical simulation estimates of VaR make no allowance for plausible events that might occur but did not actually occur in the sample period (Koenig, 2004).

In practice, main concerns are usually to obtain a long-enough run of historical data. Many practitioners point to the Basel Committee's recommendations for a minimum number of observations, requiring at least a year's worth of daily observations (i.e. 250 observations, at 250 trading days to the year). However, such a small sample size is far too small to ensure that an historical simulation approach will give accurate and robust results. In addition, as the confidence level rises, with a fixed length sample, the historical simulation VaR estimator is effectively determined by fewer and fewer observations and therefore becomes increasingly sensitive over time to small numbers of observations. At the Basel mandated confidence level of $99 \%$, the historical simulation VaR estimator is determined by the most extreme two or three observations in a one-year sample and in this case four or five observations in a oneyear sample, and this is hardly sufficient to give as a precise VaR estimate.

\footnotetext{
${ }^{1}$ Basel Committee on Banking Supervision of Bank for International Settlements.
} 


\section{GENERAL SAMPLE INFORMATION}

In this section, the estimation of market risk through application of the historical simulation Value-at-Risk calculation method is presented. A portfolio consist shares of 27 companies that are continuously traded at the Belgrade Stock Exchange (Portfolio). The data analyzed belong to a year-long period, between 22 May 2006 and 21 May 2007, for shares from the following companies: Agrobačka a.d. Bačka Topola (AGBC), AIK banka a.d. Niš (AIKB), Alfa plam a.d. Vranje (ALFA), Bambi Banat a.d. Beograd (BMBI), Banini a.d. Kikinda (BNNI), Čačanska banka a.d. Čačak (CCNB), Dunav Grocka a.d. Grocka (DNVG), Energoprojekt holding a.d. Beograd (ENHL), Galenika Fitofarmacija a.d. Zemun (FITO), Imlek a.d. Beograd (IMLK), Novosadska mlekara a.d. Novi Sad (MLNS), Metalac a.d. Gornji Milanovac (MTLC), Napred GP a.d. N. Beograd (NPRD), Planum GP a.d. Beograd (PLNM), Progres a.d. Beograd (PRGS), Pupin Telecom a.d. Zemun (PTLK), Putevi a.d. Užice (PUUE), Radijator a.d. Zrenjanin (RDJZ), Ratko Mitrović a.d. Beograd (RMBG), Soja protein a.d. Bečej (SJPT), Srbolek a.d. Beograd (SRBL), Messer Tehnogas a.d. Beograd (TGAS), Tigar a.d. Pirot (TIGR), Telefonkabl a.d. Beograd (TLKB), Univerzal banka a.d. Beograd (UNBN), Univerzal - holding a.d. Beograd (UNVR), Zorka Pharma a.d. Šabac (ZOPH).

The initial assumption was that on 22 May 2006, 10.000.000 dinars were invested into Portfolio. It was additionally assumed that the same amount was invested into each company.

Let $V o$ be the initial 10.000.000 dinar investment. Since the same amount was invested into each of the 27 companies, it means that was invested into every company:

$$
10.000 .000 / 27=370.370,370 \text { dinars }
$$

If $\mathrm{p}_{1,1}, \mathrm{p}_{1,2}, \ldots ., \mathrm{p}_{1,27}$ are the share prices as of 22 May 2006, and $\mathrm{q}_{1}, \mathrm{q}_{2}, \ldots, \mathrm{q}_{27}$ are the numbers of purchased shares, then:

$$
\begin{gathered}
\mathrm{p}_{1,1} \mathrm{q}_{1,1}=\mathrm{p}_{1,2} \mathrm{q}_{1,2}=\ldots=\mathrm{p}_{1,27} \mathrm{q}_{1,27}=370.370,370 \text { dinars } \\
\text { and } \mathrm{q}_{\mathrm{n}, \mathrm{n}}=370.370,370 / \mathrm{p}_{\mathrm{n}, \mathrm{n}} .
\end{gathered}
$$

The number of purchased shares in this example does not change, i.e. it remains constant during the observed analysis period, so only market price fluctuations and their impact on the portfolio value are being followed.

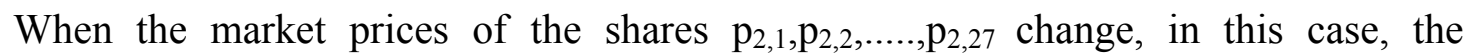
following day the portfolio value was reduced to $9.930 .981,340$ dinars. The relative portfolio value change amounts to $(9.930 .981,340-10.000 .000) / 10.000 .000=-0,00690=-0,690 \%$, which means that a loss of $69.018,66$ dinars was made.

A year later, in this case 249 working days, the portfolio value amounted was 24.521.567,951 dinars, i.e. a gain was made of $14.521 .567,951$ dinars. In this case the investment paid off because a profit of $145,22 \%$ was made. 


\section{CALCULATING VAR VALUES BY APPLYING THE HISTORICAL SIMULATION METHOD}

After creating a portfolio and establishing daily portfolio value changes for the observed period of analysis ( 249 working days), the VaR value is determined for a specific confidence level.

When applying the historical simulation method, it is essential to designate the manner of weighting historical data (market prices). According to the basic method of historical simulation, an equal weight is assigned to all data, and thus, for the above mentioned stock portfolio, it amounts to $1 / 249=0,0040160643$. It is well known that prices have different volatility in different periods of time (for instance, the natural gas price is usually more volatile in the winter than in the summer), thus the basic historical simulation approach, which unifies different volatility levels of historical data, tends to average out the volatility of aggregate returns. As a result of assigning an equal weight to all historical data, the actual risks are being underrated during certain periods and overrated during some other periods, creating potential for false effects - it is possible to get an unjustifiably high (low) VaR value due to a short period of high (low) volatility. These problems may be solved by having the historical data weighted in a suitable manner.

It is assumed herein that more recent historical data contains more information than less recent data and in that case data may be weighted according to the date of occurrence, so in this example of historical simulation less recent data are assigned smaller weight values than the more recent ones. The method used for weight determination is EWMA (exponential weighted moving average) method with the decay factor $\lambda=0,94$ (suggesting how much the value of each observation reduces on a day-to-day basis). Weights are established by the following formula:

$$
\omega_{i}=\frac{\lambda^{i-1}}{\sum_{i=1}^{T} \lambda^{i-1}}
$$

where $\omega_{i}$ is the weight associated with the $i$-th observation, $i=1,2,3, \ldots$, and $T$ is the number of observed daily rates of portfolio value change ( $\mathrm{T}=249$ working days).

In the following step, the rates of change in portfolio value (return rates) are ranked from the smallest to the largest, and the sequence of weights based on the date of occurrence is also changed accordingly. Cumulative weights are subsequently calculated:

$$
\omega_{i, \text { cum }}=\omega_{i-1}+\omega_{i-1, \text { cum }}
$$

where $\omega_{i}$ is the weight associated with the $i$ - th observation, $i=1,2,3, \ldots$. , and $\omega_{i, \text { cum }}$ is the cumulative weight associated with the $i$ - th observation.

The confidence level for each $i$ - th return rate is determined on the basis of the cumulative weights, by assigning a confidence level of $1-\omega_{i, \text { cum }}$ to each return rate.

The last step is the calculation of portfolio VaR for a specific confidence level. In this example the VaR values are calculated on the basis of one-day and ten-days forecast periods, for the confidence levels of $90 \%, 95 \%$ and $99 \%$, as the absolute values of return rates for 
given confidence levels (Table 1, Figure 1, Figure 2, Figure 3), by applying the basic historical simulation method and the following results were obtained:

Table1.

VaR values calculated for the portfolio consisting of shares that are continuously traded at the Belgrade Stock Exchange, by applying basic historical simulation method

\begin{tabular}{|c|c|c|}
\hline Historical simulation & 1-day & $\mathbf{1 0 - d a y s}$ \\
\hline VaR (90\%) & $0,729 \%$ & $2,31 \%$ \\
\hline VaR (95\%) & $0,9333 \%$ & $2,95 \%$ \\
\hline VaR (99\%) & $2,4002 \%$ & $7,59 \%$ \\
\hline
\end{tabular}

Source: Obadović, M. (2008).

The broken line in the figures 1 - 6 represents data on 88 consecutive VaR values, estimated on the basis of data on 249 value changes for the portfolio consisting of 27 shares that are continuously traded at the Belgrade Stock Exchange.

The black line in the figures 1 - 6 represents data on 88 consecutive actual portfolio returns to which VaR evaluations are compared.

\section{Figure 1.}

Graphic of VaR values obtained by the basic historical simulation method, for the portfolio consisting of 27 shares that are continuously traded at the Belgrade Stock Exchange with the error risk of 0,01 and decay factor $\lambda=1$

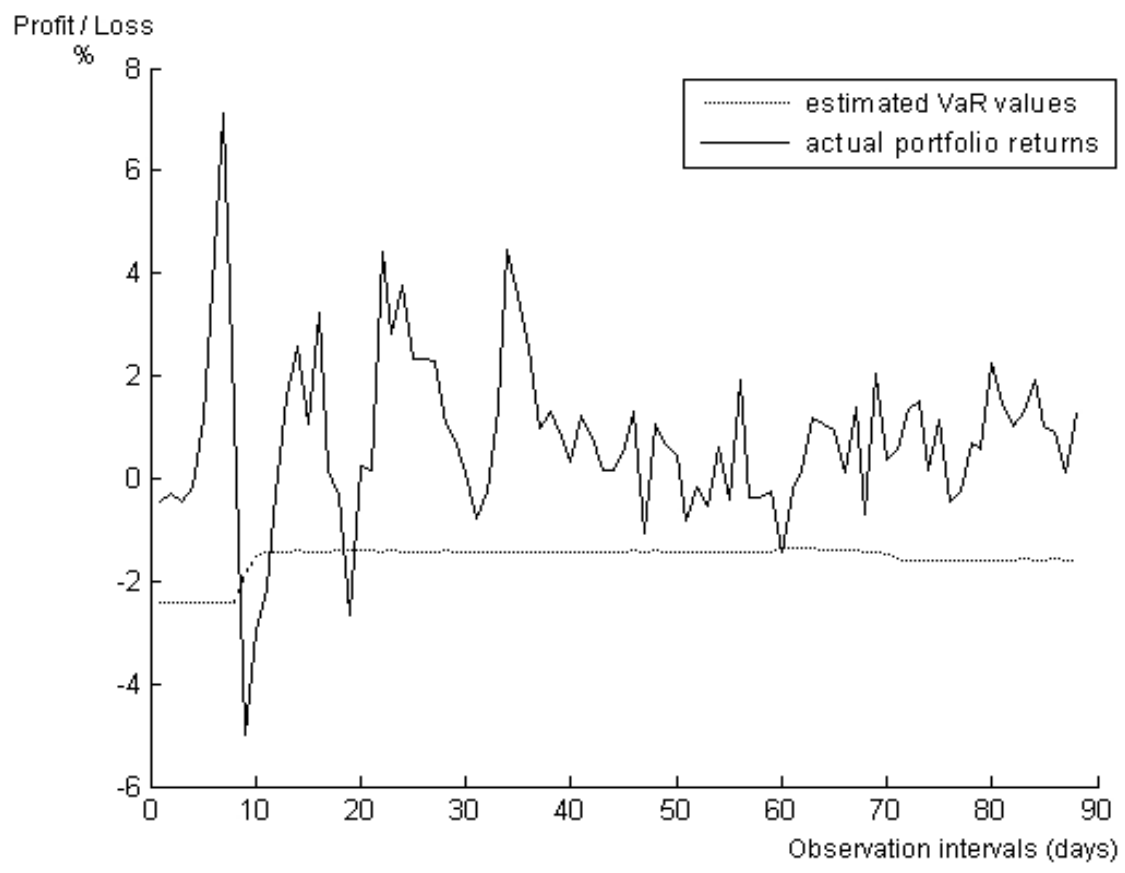

Source: Obadović, M. (2008). 


\section{Figure 2.}

Graphic of VaR values obtained by the basic historical simulation method, for the portfolio consisting of 27 shares that are continuously traded at the Belgrade Stock

Exchange with the error risk of 0,05 and decay factor $\lambda=1$

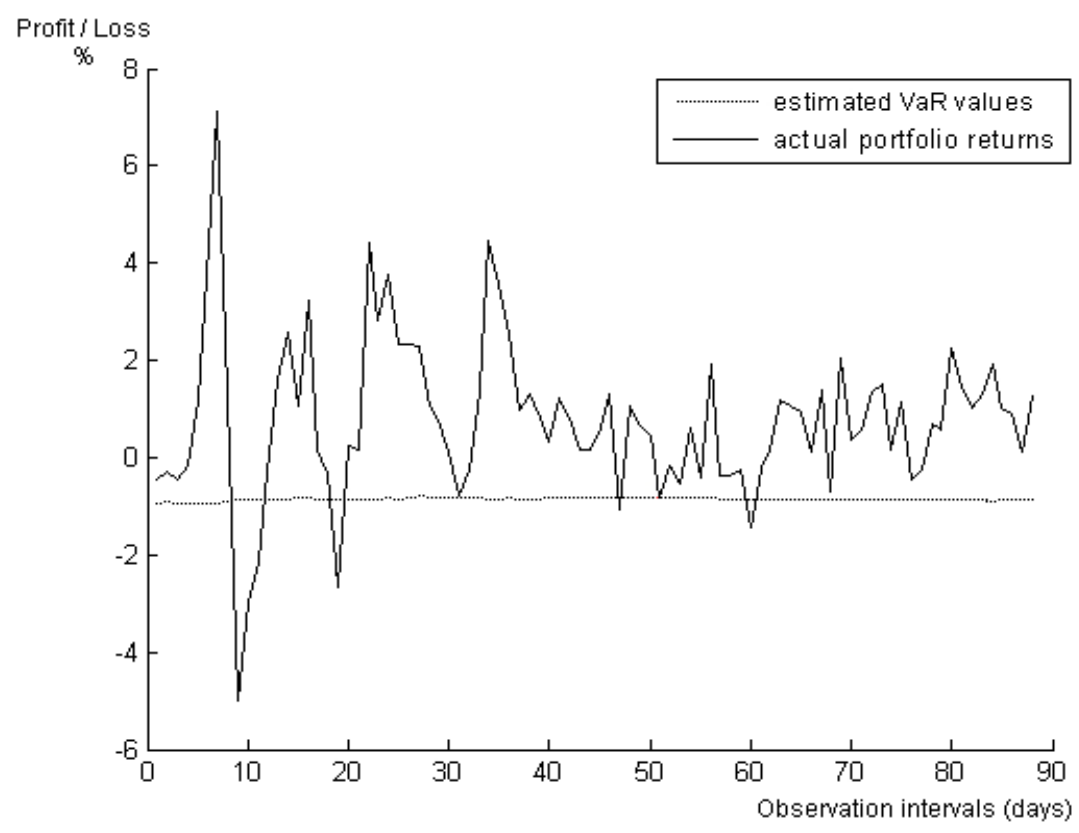

Source: Obadović, M. (2008).

\section{Figure 3.}

Graphic of VaR values obtained by the basic historical simulation method, for the portfolio consisting of 27 shares that are continuously traded at the Belgrade Stock Exchange with the error risk of 0,1 and decay factor $\lambda=1$

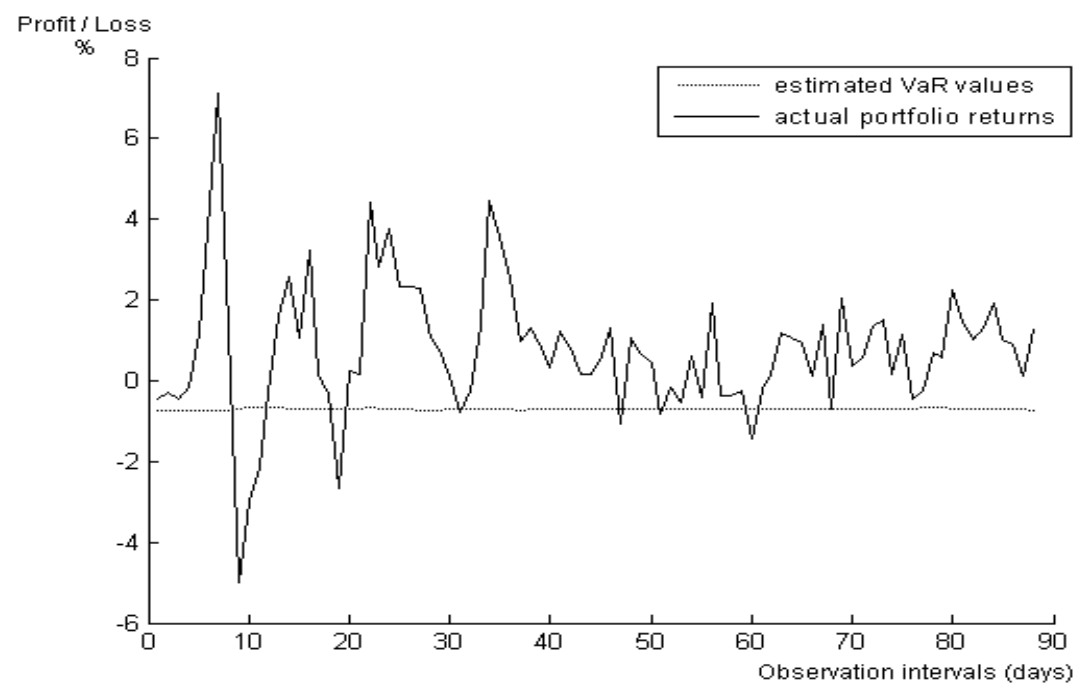

Source: Obadović, M. (2008).

In this example the VaR values are calculated on the basis of one-day and ten-days forecast periods, for the confidence levels of $90 \%, 95 \%$ and $99 \%$, as the absolute values of 
return rates for given confidence levels (Table 1, Figure 1, Figure 2, Figure 3), by applying the EWMA (exponential weighted moving average) historical simulation method and the following results were obtained:

\section{Table2.}

VaR values calculated for the portfolio consisting of shares that are continuously traded at the Belgrade Stock Exchange, by applying EWMA historical simulation method

\begin{tabular}{|c|c|c|}
\hline Historical simulation & 1-day & 10-days \\
\hline VaR (90\%) & $2,0592 \%$ & $6,51 \%$ \\
\hline VaR (95\%) & $2,8913 \%$ & $9,14 \%$ \\
\hline VaR (99\%) & $4,4754 \%$ & $14,15 \%$ \\
\hline
\end{tabular}

Source: Obadović, M. (2008).

\section{Figure 4.}

Graphic of VaR values obtained by the EWMA historical simulation method, for the portfolio consisting of 27 shares that are continuously traded at the Belgrade Stock Exchange with the error risk of 0,01 and decay factor $\lambda=0,94$

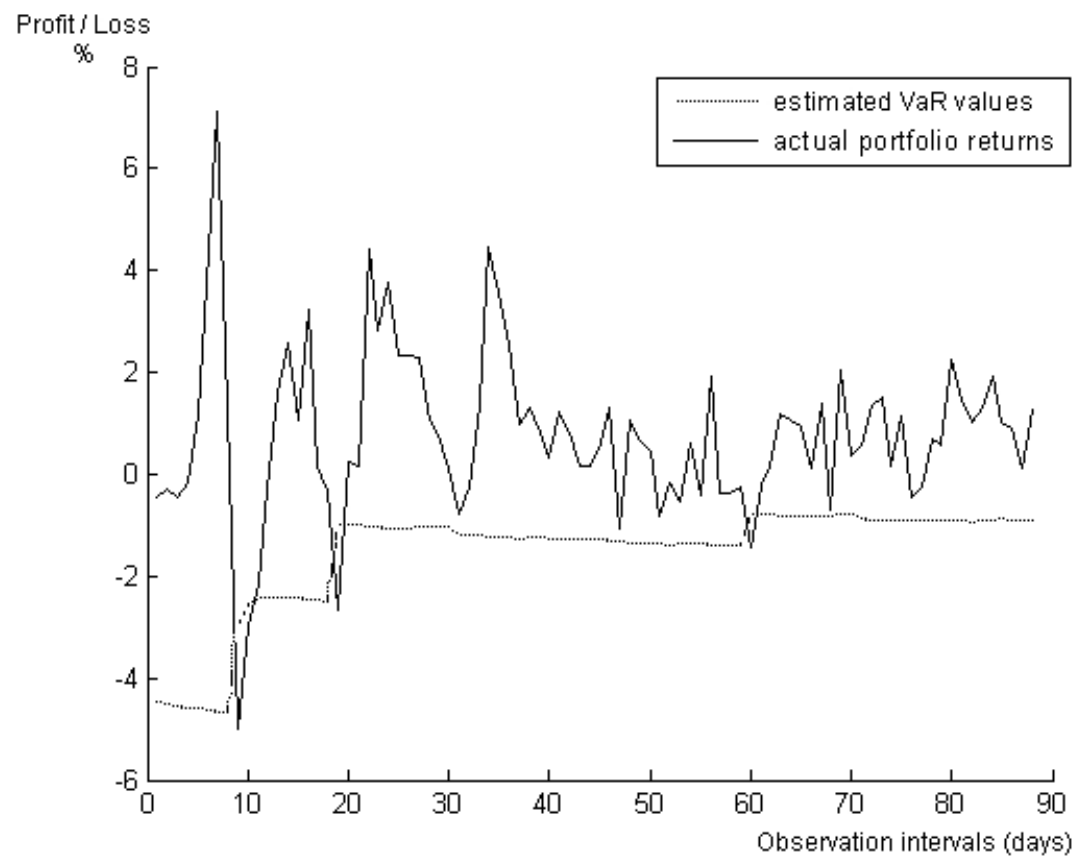

Source: Obadović, M. (2008). 


\section{Figure 5.}

Graphic of VaR values obtained by the EWMA historical simulation method, for the portfolio consisting of 27 shares that are continuously traded at the Belgrade Stock Exchange with the error risk of 0,05 and decay factor $\lambda=0,94$

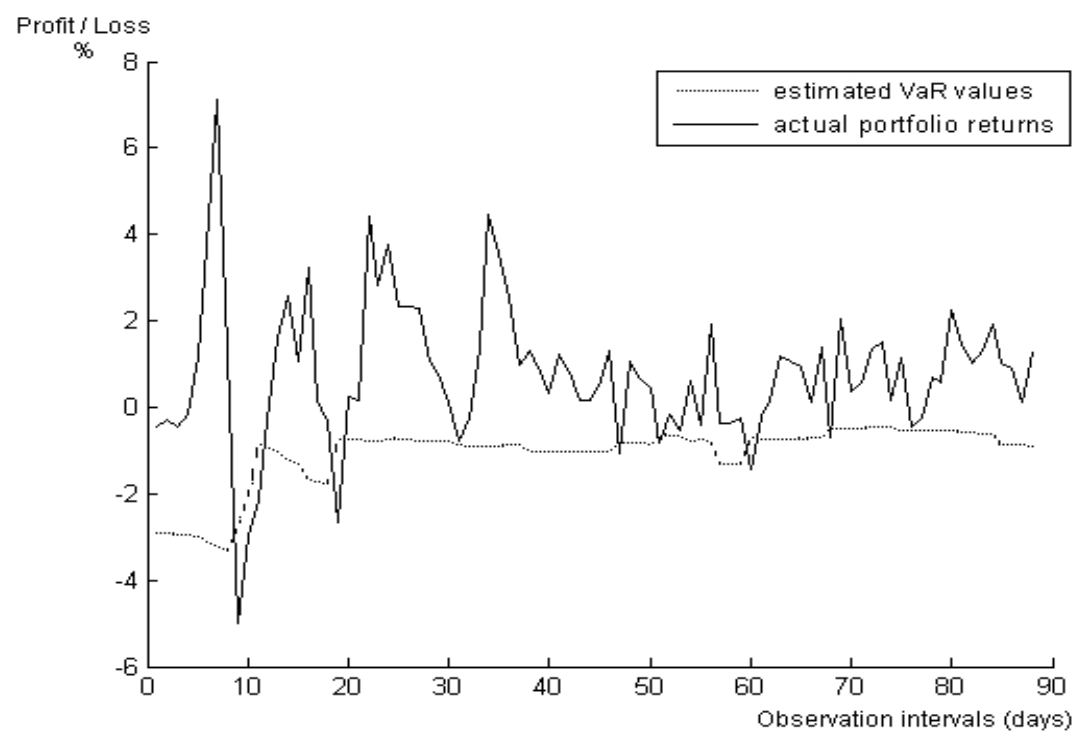

Source: Obadović, M. (2008).

Figure 6.

Graphic of VaR values obtained by the EWMA historical simulation method, for the portfolio consisting of $\mathbf{2 7}$ shares that are continuously traded at the Belgrade Stock Exchange with the error risk of 0,1 and decay factor $\lambda=0,94$

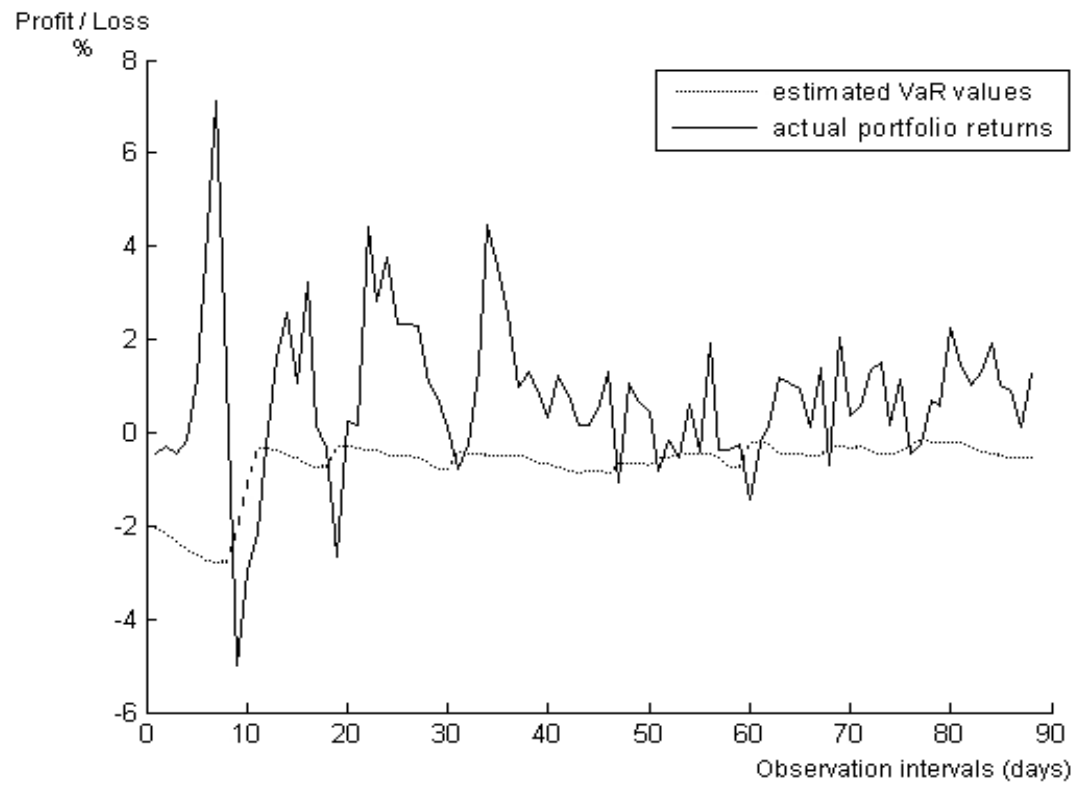

Source: Obadović, M. (2008). 


\section{MODEL VERIFICATION BASED ON THE FAILURE RATE}

The simplest way of verifying model accuracy is to record the failure rate, which gives the proportion of how many times $\mathrm{VaR}$ has exceeded the expectations in a given sample.

In order to determine whether these models predict risks well, VaR is evaluated for 88 consecutive days, for Portfolio. The following tables demonstrate how many times the loss was larger than predicted by VaR:

Table3.

\section{Review of the calculated values - how many times the actual loss exceeded the previous day VaR for Portfolio using the historical simulation method $(T=88)$}

\begin{tabular}{|c|c|c|}
\hline Historical simulation & $\boldsymbol{\lambda}=\mathbf{1}$ & $\boldsymbol{\lambda}=\mathbf{0 , 9 4}$ \\
\hline $\mathrm{p}=0,01$ & $\mathrm{~N}=5$ & $\mathrm{~N}=4$ \\
\hline $\mathrm{p}=0,05$ & $\mathrm{~N}=7$ & $\mathrm{~N}=8$ \\
\hline $\mathrm{p}=0,1$ & $\mathrm{~N}=9$ & $\mathrm{~N}=12$ \\
\hline
\end{tabular}

Source: Obadović, M. (2008).

where $\mathrm{T}$ - total number of consecutive VaR predictions, and $\mathrm{N}$ - number showing how many times the actual loss exceeded the VaR from the previous day.

Subsequently, at the given confidence level, we need to know whether $\mathrm{N}$ is too small or too large, under the null hypothesis that $\mathrm{p}$ is a true probability. Once the failure rate is calculated as N/T and compared to the left tail probability, e.g. $\mathrm{p}=0,01$, which is used to determine $\mathrm{VaR}$ evaluation, if they match the VaR evaluation was correct, and if they differ significantly the model has to be rejected.

For the sake of illustration, the confidence level is set at $95 \%$. This number does not refer to the quantitative level $p$ that was selected as the VaR, which might be $p=0,01$ for instance. This confidence level refers to the decision on whether to reject the model or not. It is generally set at $95 \%$ because this corresponds to two standard deviations under a normal distribution (Jorion, 1997).

Kupiec (1995) developed the confidence regions for such a test. These regions are defined by the tail points of likelihood ratio:

$$
L R=-2 \ln \left[(1-p)^{T-N} p^{N}\right]+2 \ln \left[\left(1-(N / T)^{T-N}(N / T)^{N}\right],\right.
$$

which is distributed through $\chi^{2}$ test with one degree of freedom under the null hypothesis that $\mathrm{p}$ is a true probability.

For example, with data for the portfolio consisting of local shares $(\mathrm{T}=88)$ it could be expected that $\mathrm{N}=\mathrm{pT}=10 \% \times 88=8,8$ deviations will be observed. However, the regulator will not be able to reject the null hypothesis as long as $\mathrm{N}$ is within the confidence interval $[2<$ $\mathrm{N}<15]$. Values of $\mathrm{N}$ greater or equal to 15 suggest that $\mathrm{VaR}$ model represents the probability 
of large losses lower than they actually are; values of $\mathrm{N}$ that are less than or equal to 2 suggest the VaR model is too conservative. The following table shows the regions in which the model is not rejected on the basis of significance $\alpha=0,05$.

\section{Table4.}

Model verification: Regions in which the model is not rejected at the significance level of 0,05

\begin{tabular}{|l|c|}
\hline Historical simulation & Portfolio $(\mathbf{T}=\mathbf{8 8})$ \\
\hline $\mathrm{p}=0,01$ & $\mathrm{~N}<4$ \\
\hline $\mathrm{p}=0,05$ & $\mathrm{~N}<9$ \\
\hline $\mathrm{p}=0,1$ & $2<\mathrm{N}<15$ \\
\hline
\end{tabular}

Source: Obadović, M. (2008).

However, this table still shows the disturbing fact that for small values of VaR parameter $p$, it becomes harder to verify the deviations. For example, the rejection region of $95 \%$ for $\mathrm{p}=0,01$ and $\mathrm{T}=88$ is $[\mathrm{N}<4]$. Therefore it is impossible to state with certainty whether $\mathrm{N}$ is abnormally small or the model systematically overestimates the risk.

It should also be emphasized that this interval, expressed as the N/T ratio, decreases with larger samples, i.e. with more data it should be easier to reject a faulty model.

Revealing systematic ambiguities becomes harder with lower $\mathrm{p}$ values, because they correspond to rare occurrences. This explains why some banks prefer higher values for $\mathrm{p}$, e.g. $5 \%$ (which translated as the confidence level $\mathrm{c}=95 \%$ ), in order to be able to observe a sufficient number of deviations to validate the model.

The following table presents whether a model is acceptable or not, on the basis of Kupiec likelihood ratio.

\section{Table5.}

Model verification for Portfolio using the historical simulation method $(\mathrm{T}=88)$

\begin{tabular}{|l|l|l|}
\hline Historical simulation & $\boldsymbol{\lambda}=\mathbf{1}$ & $\boldsymbol{\lambda}=\mathbf{0 , 9 4}$ \\
\hline $\mathrm{p}=0,01$ & rejected & rejected \\
\hline $\mathrm{p}=0,05$ & accepted & accepted \\
\hline $\mathrm{p}=0,1$ & accepted & accepted \\
\hline
\end{tabular}

Source: Obadović, M. (2008). 


\section{CONCLUSIONS}

In this paper, the estimation of market risk through application of the historical simulation Value-at-Risk calculation method for portfolio that consist of shares of 27 companies that are continuously traded at the Belgrade Stock Exchange is presented. In order to determine whether these models predict risks well, VaR is evaluated for 88 consecutive days, for this portfolio. This paper presents whether a model is acceptable or not, on the basis of Kupiec likelihood ratio.

Using the historical simulation method on the portfolio consisting of shares traded in the local market, it has been shown under null hypothesis that $\mathrm{p}=0.05$ is an accurate probability, based on the Kupiec likelihood ratio distributed through $\chi 2$ test with one degree of freedom, so this method is accepted in all cases except when applying the historical simulation method to the portfolio at the confidence level of $99 \%$, wherein this model shows the probability of larger losses to be smaller than it actually is.

Applying this method in local market conditions is risky at a confidence level of 99\%, because that level corresponds to extremely rare events. This explains why some banks prefer lower confidence levels, in order to be able to observe a sufficient number of deviations for the purpose of model validation. A multiplication factor is thus applied to transform VaR into secure capital to be set aside for protection from market risk.

\section{REFERENCES}

Alexander, C. (2008), Market Risk Analysis, Volume IV: Value at Risk Models, John Wiley \& Sons Inc.

Alexander, C. (2005), "The present and future of financial risk management", Journal of Financial Econometrics, Volume 3:3-25.

Bingham, N. H. and R. Kiesel (2000), Risk-Neutral Valuation, Pricing and Hedging of Financial Derivatives, Springer-Verlag, London.

Bluhm, C., L. Overbeck and C. Wagner (2001), An introduction to credit risk modeling, Chapman \& Hall, Boca Raton, Florida.

Božina, M. (2006), "Pravni i ekonomski aspekti regulacije poslovnih banaka u procesu ekonomske i monetarne integracije Republike Hrvatske", Ekonomska istraživanja, Pula, 19 (1-2):107-117.

Chen, S. X. and C. Y. Tang (2005), "Nonparametric inference of value-at-risk for dependent financial returns", Journal of Financial Econometrics, Volume 3:227-55.

Crosbie, P. (1999), Modeling default risk, KMV Corporation.

Crouhy, M., R. Mark and D. Galai (2001), Risk Management, McGraw-Hill, New York.

Ding, Z., C. W. J. Granger and R. F. Engle (1993), “A long memory property of stock market returns and a new model”, Journal of Empirical Finance, Volume 1:83-106.

Dorfman, M. (2005), Introduction to Risk Management and Insurance, Prentice Hall, New Jersey.

Dowd, K. (2005), Measuring market risk, John Wiley \& Sons Ltd, West Sussex, England 
Dowd, K. (1998), Beyond Value at Risk, The new science of risk management, John Wiley \& Sons Ltd, West Sussex, England

Esch, L., R. Kieffer and T. Lopez (2005), Asset and Risk Management, Wiley, West Sussex.

Fabozzi, F. J., L. Martellini and P. Priaulet (2006), Advanced Bond Portfolio Management, John Wiley \& Sons Inc., Hoboken, New Jersey.

Fernandez, C. and M. Steel (1998), "On Bayesian modelling of fat tails and skewness", Journal of the American Statistics Association, Volume 93:359-71.

Finger, C. C. (1999), Conditional approaches for creditmetrics portfolio distribution, CreditMetrics ${ }^{\mathrm{TM}}$ Monitor.

Gencay, R. and F. Selcuk (2004), "Extreme value theory and value-at-risk: relative performance in emerging markets", International Journal of Forecasting, Volume 20:287303.

Gencay, R., F. Selcuk and A.Ulugulyagci (2003), "High volatility, thick tails and extreme value theory in value-at-risk estimation", Insurance: Mathematics and Economics, Volume 33:337-56.

Hall, P., C. L. Wolff and Q. Yao (1999), "Methods for estimating a conditional distribution function", Journal of American Statistical Association, Volume 94:154-63.

Holton, G. A. (2003), Value at Risk: Theory and Practice, Academic Press, Amsterdam.

Jorion, P. (2001), Value at Risk, McGraw-Hill, New York, NY, .

Jorion, P. (1997), Value at Risk: The New Benchmark for Controling Market Risk, McGrawHill, Chicago, IL, .

Loretan, M. and P.C.B. Phillips (1994), “Testing the covariance stationary of heavy-tailed time series", Journal of Empirical Finance, Volume 1:211-48.

Karatzas, I. and S. E. Shreve (1998), Methods of Mathematical Finance, Springer-Verlag, New York.

Koenig, D. R. (2004), Volume I: Finance Theory, Financial Instruments and Markets, PRMIA Publications, Wilmington, DE.

Koenig, D. R. (2004), Volume II: Mathematical Foundations of Risk Measurement, PRMIA Publications, Wilmington, DE.

Koenig, D. R. (2004), Volume III: Risk Management Practices, PRMIA Publications, Wilmington, DE.

Kupiec, P. (1995), “Techniques for Verifying the Accuracy of Risk Measurement Models", Journal of Derivatives, Volume 2:73-84.

Marrison, C. (2002), The Fundamentals of Risk Measurement, McGraw-Hill, New York .

Morgan Guaranty Trust Company (1994), RiskMetrics-Technical Document, Morgan Guaranty Trust Company, Global Research, New York.

Obadović, M. (2008), Comparative application of methods for estimating market risk analytical method and historical simulation method, magisters thesis, Faculty of Economics, University of Belgrade, Belgrade.

Silva, A. and B. Mendes (2003), "Value-at-risk and extreme returns in Asian stock markets", International Journal of Business, Volume 8:17-40. 


\title{
PROCJENA TRŽIŠNOG RIZIKA PRIMJENOM METODA POVIJESNE SIMULACIJE U PERIODU RASTA BURZOVNIH POKAZATELJA NA BEOGRADSKOJ BURZI
}

\begin{abstract}
SAŽETAK
U Srbiji je postojao period rasta investicija, koji se odražavao i na rast burzovnih pokazatelja. Cilj ovoga rada je da procijeni tržišni rizik u periodu rasta burzovnih pokazatelja na srpskom tržištu, primjenom metoda povijesne simulacije, na portfolio koji se sastoji od svih akcija kojima se kontinuirano trgovalo na Beogradskoj burzi a za koje su u danom trenutku postojali potrebni podaci, obzirom da je srpsko burzovno tržište bilo mlado tj. praktično u nastajanju. Izvršena je verifikacija modela na više nivoa pouzdanosti koja je pokazala da je model podcijenio postojeći rizik na nivou pouzdanosti od $99 \%$.
\end{abstract}

KLJUČNE RIJEČI: tržišni rizik, Model vrijednosti rizika (VaR), metoda povijesne simulacije, financijsko tržište 